\title{
KELLIE'S CASTLE AND THE INDIAN LABOUR IN BATU GAJAH, PERAK, 1870-1926
}

\author{
Parameswari Krishnan* \\ Universiti Selangor (UNISEL), Malaysia \\ J.Hinduja Jayer Raman** \\ Said Darkasi**** \\ Universiti Selangor (UNISEL), Malaysia
}

\begin{abstract}
This paper will focus on the history of Kellie 's Castle, built by William Kellie Smith in Batu Gajah, Perak, between the period 1870 to 1926 and the relationship between Kellie Smith and the Indian plantation labourers. This would indicate that the writing of the history of the state of Perak would not be complete without touching Kellie's Castle in Perak with the first elevator shaft in Malaya with some other peculiarities as 3 tunnels under the castle. Needless to say, Kellie had a clear fascination and deep involvement with Indian culture and that appeared to have been the motivation behind his actions. The Historical studies like these that focus on the Indian community in every state in Malaya is very important because the writings are very limited and would give a clear picture of their social life especially in plantation. This paper used a variety of sources especially National Archives records that have never been used by any previous researchers. The main question of this paper is focused on the history of the most historic buildings and relations between India labour in Malaya during the British era. The whole study shows that, kellies castle not only became important in British times but it also carries a great meaning in the history of Perak and Malaysia. This is because the uniqueness of the construction of the building makes us amazed because it is a combination of construction from various countries. In the meantime, the Indian community plays a big role in build it and without their sacrifice we cannot feel the history of the kellies castle building that exists today in Batu Gajah, Perak.
\end{abstract}

Keywords: Kellie's Castle, Kellie's Foly, William Kellie Smith, Batu Gajah, Indian labour

\section{Introduction}

Local history plays an important role in the development of history in this country. Local history pays attention to historical events that take place in an area. In this context, local history is seen to occupy the lowest position in the national historical hierarchy. National history means a single historical event that has relevance and relationship with the history of the country as a whole. In contrast to local history which sometimes has no significance in national history and is only important to an area only. Even so, this does not mean that local history is seen as less important. Even a combination of various local histories can form an important historical view and be able to revive national history.

The local history that will be noted in the writing of this paper is about Kellie's Castle and its relationship with the Indian community which is the main subject of discussion. As is well known, the Indians in this country have an invaluable history and heritage. Writing about Indians in this country either before or after independence seems to be general in 
nature. In fact, the history of the Indians by focusing on an area or district is almost not given attention in any scholarly writing before. If anything, it is only in the form of general and the writing is still in the early stages and not comprehensive. Writing about a community based on one district or state is able to describe various things that are overlooked in writing history in general. This will further enrich the source of writing about a race either to be enjoyed for now or in the future. Sources of writing especially about Indians by focusing on an area will unravel many aspects in depth about a community. So, this will make the history of an area and the community important.

So this paper is significant in displaying the history of a 'palace' which has 'elevator shaft' first in Malaya called 'Kellie's Castle' or 'Kellie's Folly'. This paper also looks at the relationship between farm Indian laborers and William Kellie Smith around 1870 to 1926. This study is important as most people may not be able to know the true history and development of Kellie's Castle in the period 1870 to 1926. This is due to all the information still found in official government documents in the National Archives. Although information regarding the history of Kellie's Castle can be obtained from internet sources, the information is not authoritative and at the same time, much more information is not stated in detail. In addition, the pictures included in this paper will also give a broad picture of a place or area. Exposure to these pictures will further enrich writing about the history of a building or a place.

One of the researchers who played a big role in studying the aspects involving Kellie's Castle was Tan Sri Dato 'Dr. Mubin Sheppard who is a European (retired 'Malayan Civil Service', former first director of the National Archives of Malaysia, editor of 'The Planter' magazine, and editor of the Journal of Malayan Royal Asiatic Society). His contribution was so great in gathering all the information about William and the castle. He took the initiative by contacting the family and heirs of William Kellie Smith who was in London. This effort was made after his arrival in Taiping as a resident assistant in 1931. The information collected was subsequently published in the form of official government documents. Without the efforts taken by him, of course we would not be able to enjoy the life history of Kellie Smith and Kellie's Castle today.

\section{William Kellie Smith}

Wiiliam Smith was born on $1^{\text {st }}$ March 1870 . His father was a Scottish farmer and his mother's maiden name was Kellie. The name of the farm where he was born was "Easter Kellas", near Elgin. When young William was about twenty he followed the example of many of his Scottish contemporaries and travelled to the Malay States to look for employment. Before long he was engaged by an estates owner and developer named Alma Baker, to help him in the construction of public roads in South Perak, on contract. With his share of the proceeds William Smith acquired one thousand acres of jungle land in the district of Kinta and planted it with rubber. As soon as the trees were tappable he formed, which he called the Kellas Rubber Company, with shares available on the London stock market. Rubber shares at that time were in keen demand and they paid good dividents. ${ }^{1}$

Wiiliam took the name of 'Kellie Smith' combining the sir name of his father and mother, and gave the name of his father's farm to his rubber estate. When he acquired a second rubber estate, he renamed the first 'Old Kellas', and the new one 'Kinta Kellas Rubber Estate'. To add his good fortune, Tin was found on land adjoining his estate and he acquired the land and named the new company 'Kinta-Kellas Tin Dredging'. It too was a profitable investment. $^{2}$ 
In 1902, a wealthy and high-spirited bachelor, William sailed for England, attended to business affairs in the Company's London Office and was appointed 'Resident General Manager' of his estates. He continue to hold the post until his death. He was an attractive young man, tall, strong and a roguish twinkle in his eyes, which was still there thirty years later. ${ }^{3}$ On his way back to Penang he met Agnes Smith, an attractive young woman from London, who was travelling on the same ship, and married her. She had never lived overseas before and it is doubtful whether she ever adapted herself fully to the life and interests of her husband. About a year later, she bore him a daughter, Helen Agnes. ${ }^{4}$

Figure 1: William Kellie Smith

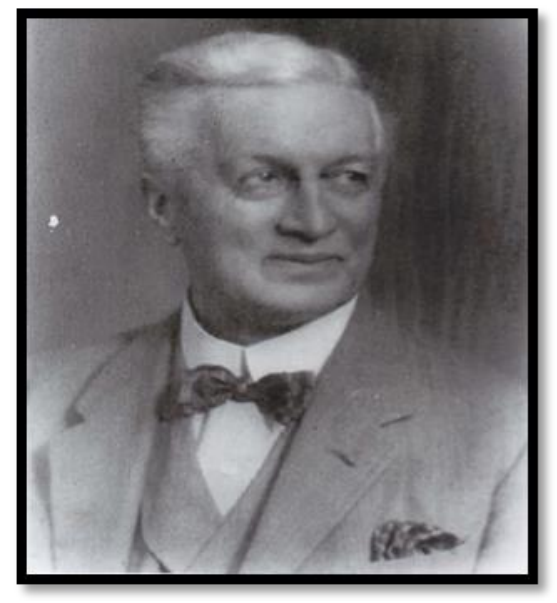

Source: National Archive of Malaysia, Kuala Lumpur

\section{Kellie's Castle}

Soon afterwards, William decided to build a very large and ornamental mansion for his wife and baby daughter, and chose a site on a low hill, at one and of the estate, not far from the only public road in the neighbourhood. He also laid out a spacious garden, with grass lawns, tall palms, flowering shrubs and a lake. ${ }^{5}$

Qualified Architects were rare, and William chose the design of the Federal Secretariat in Kuala Lumpur as a model for his residence. Photos taken some years later in detail, how closely the building followed the original structure. He called his new home 'Kellas House' and it quickly became famous. It even received a short mention in the 'Financier', which was published in London on $15^{\text {th }}$ September 1911. The paragraph read, 'The General Manager's residence is probably unique in point of style and size in the Middle East World' ${ }^{6}$

Kellie Smith travelled extensively and acquired interests in Siam and Singapore. On a visit to India the palaces of Princes attracted him, and some years later, after another profitable venture, he decided to erect a much larger residence on a ridge, only fifty yards from Kellas House. He must have employed a trained architect, but no plans can now be found. This project may have been stimulated by the birth of a son and heir in 1915, who he named Anthony. ${ }^{7}$

In that year he began to assemble materials and workmen on the site. 70 tough workers, mostly from Madras, were employed. Bricks and marble were imported from India. 
The First World War he generated additional profits for rubber planters and his plans expanded accordingly. But when the War ended in November 1918, a deadly epidemic of a particularly virulent type of Influenza (Spanish Flu) spread from Europe to Asia and ravaged the labourers on rubber estates, including those on 'Kellas' and killed many of the workers. Kellie Smith was a paternal estate manager, and spoke both Malay and Tamil fluently. When therefore a delegation of his Tamil labourers asked him to help them to build a Temple on the edge of the Estate, where they could pray to their gods for protection, he stopped all work on the construction of his second house and transferred builders and plasters to a site close to the main road. The temple was to be a substantial building and included a long wall which separated the main courtyard from the inner sanctuary. Along the top of the wall Indian Plasters constructed a row of figures of Hindu gods, accompanied by their supporting wives and followers, and painted them in appropriately bright colours. A few feet from the central deity a less ornate figure was added, wearing a 'Topee' and the conventional dress of a 'Dorai' and bearing an unmistakable likeness to Kellie smith himself. The temple was duly completed and stands close to the main road to Batu Gajah to this day. ${ }^{8}$

Work on the new mansion was then renewed. It resembled no other in the country and included a number of features which had never been seen in Malaya before: a Lift-shaft, which extended from the basement to the second floor, a spacious wine-cellar with numerous compartments, in the basement, approached by a winding staircase, and at the far end of the building, on the roof on the second floor, a full sized outdoor tennis court was laid out, with a cement surface. It was now 1919, the war had ended and Mrs. Kellie Smith longed to return to London. She may not have shared her husband's infatuation for the new building and he arranged for her to take the earliest possible sea passage to England, taking their little son, then only six years old. Helen his daughter, aged about sixteen, remained with her father. Just before the war, Kellie Smith had acquired four of the latest models of Motor Cars and had built a large and ornate garage near the house. ${ }^{9}$

Figure 2: Kellie Smith at the wheel with his wife beside him and a Malay syce seated at the back.

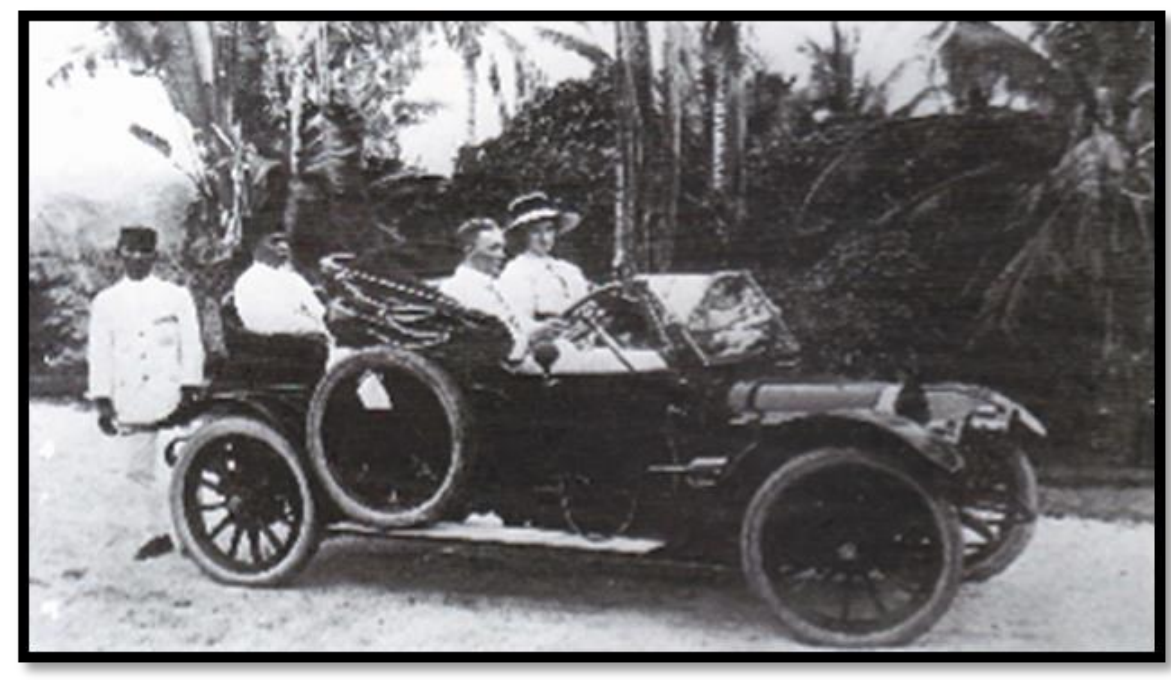

Source: National Archive of Malaysia, Kuala Lumpur. 
Kellie Smith remained on his estate until the middle of 1926. The new mansion was then sufficiently well advanced for the lift to be imported and installed. The residential part of the new house was complete. The Indian plastered had executed delicate designs along the top of the inner walls of six large bedrooms. A varandah, ran the length of the building, on the floors. On the ground floor, a series of oval arches, reminiscent of Moon Gates, provide access to the well shaded sitting rooms. The upper varandah bore no resemblance to the design below and was bordered by a low brick parapet, supporting a series of double brick pillars. Its seemed appropriate for a royal palace, with ample accommodation for a numberless household, than for a Scottish Tycoon, living almost alone. His daughter Helen, preceded him, followed not long afterwards by Kellie Smith. He had not visited London since before the First World War and there were many matters for the 'Resident General Manager' to discuss with his fellow company directors. ${ }^{10}$

He had always been interested in speculative venture, one at least in Siam and before he returned to Perak late in 1926, he arranged to visit Portugal. There is no written record of his reason for doing so, but a legend has survived which hints that he was interested in obtaining a Concession in Portuguese Timur, and that he decided to go to Lisbon to negotiate with senior Portuguese officials. While staying in a Hotel in Lisbon in midwinter, he caught a chill. After years spent in the tropics he was unfamiliar with the hazards of winter weather and he developed Pneumonia. He died after a short illness and was buried in the British cemetery on $11^{\text {th }}$ December 1926 . The inscription on his gravestone reads:

In affectionate memory of William Kellie Smith, who born in Elgin, Scotland, on $1^{\text {st }}$ March 1870 and spent 37 years of his life in the Federated Malay States and who died at Lisbon on $11^{\text {th }}$ December 1926 aged 56 years. $^{11}$

His sudden death put an immediate end to the building of his mansion. Mrs. Kellie Smith never returned to Malaya and sold her husband's property to the Directors of his Rubber Companies. Later it came under the ownership of Harrison and Crosfield Sdn. Bhd. Neither of the children ever saw their first home again. Anthony Kellie Smith was killed in the Second World War, but he had married and had a son, named David Anthony Kellie Smith, who visited his grandfather's estate and his abandoned residence in 1981.Helen Agnes married and had two daughters. One is particular, Frances Boston Smith, kept the photographs which are reproduced here and hopes that at some time she will be able to visit Malaysia and her grandfather's castle. ${ }^{12}$

The house is sometimes referred to as 'Kellie's Castle' and sometimes 'Kellie's Folly'. The word Castle is a misomer: palace would be much more appropriate and it is probable that the inspiration for the building lay in India. It is a tribute to the skilled workmanship of the builders and planters that so much of the interior remains in such a remarkably good state of preservation. But it is empty. It is not difficult to imagine the feeling of overwhelming distress which may have killed the mind of William Kellie Smith, as he lay helpless, alone and near the death in Lisbon in $1926 .{ }^{13}$

If you believe in the ghostly presence of some invisible but restless spirit in a place to which he was deeply attached, then you may accept the thought that the ghost of William Kellie Smith still lingers in the corridors of his beloved palace. He would not wish to alarm a 
visitors, nor to do them any harm. Rumours of a proposal to convert his building into a Tourist attraction would have his full support. Many fictional embellishments of this saga have been published. But the account given above is the result of several years to which members of the family have contributed. There is no mystery; there are no underground passage; but there is quite enough astonishing reality to justify a visit to this unique building.

The castle would be an anachronism in today's world, but it is remarkable in encapsulating the ambitions and endeavours of a man in the $20^{\text {th }}$ century who in build with care and concern for climate and family comfort, to impress and to function as a home and in doing so achieved a unique blend of architectural motifs and combined them overall with the openness of the Malay domestic tradition. ${ }^{14}$

Figure 3: Kellie's Castle or Kellie's Folly

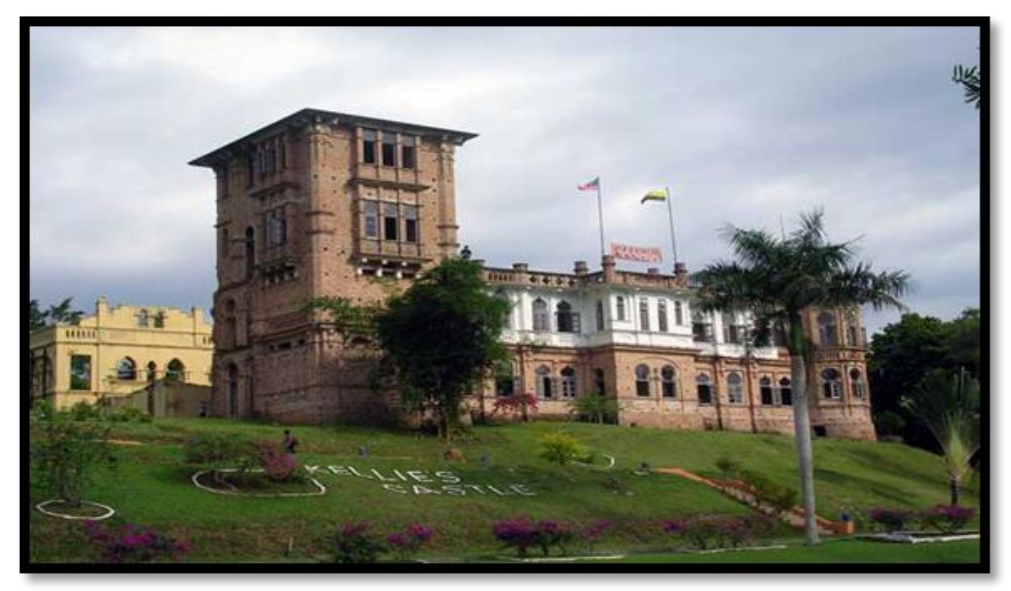

Source: National Archive of Malaysia, Kuala Lumpur

\section{Kellie Smith and The Relationship Between The Indian Labourers}

Initially, Indian labourers were brought in to work in sugar cane and coffee plantations in Penang. They were brought in for a short fixed period, usually within three years, under an indentured or contract system. ${ }^{15}$ The labourer was not fully informed about the situation in Malaya and the difficulty they faced regarding the low wage compared to the hard work done. Agents were sent from Malaya to Indian villages to recruit labourers by telling grand tales about the situation in Malaya. Those in India were told they would be handsomely paid for relatively easy work and they would only need to work for a short period. ${ }^{16}$

The situation grew direr with the rapid growth of the rubber industry. This situation drew the attention of the Colonial Office and in 1872 the Indian Government was persuaded to revoke the ban. However, this did not lead to improvement in labour welfare. The estate labourer was only paid 20 to 30 cents a day. In 1897, all Acts established to prevent Indian entry into Malaya were withdrawn. In the same year the kangani system was introduced. ${ }^{17}$ Far from ensuring labour welfare, this system was introduced to facilitate their entry into Malaya. The detested contract system, condemned as cruel, was continued through the kangani system. The kangani system helped organise the entry of Indian labour into Malaya. ${ }^{18}$ 
The Indian Immigration Committee was formed in 1907 to streamline the entry of Indian labourers into Malaya. From 1909, Indian labourers were exempted from fare. Two years later The Tamil Immigration Fund was created to bear the cost of transferring labour from Madras and look after their welfare, including their dependents. ${ }^{19}$ In 1910, the contract system, long considered unfair, was abolished. This act made the kangani system the sole system in the transfer of Indian labour to Malaya until $1938 .^{20}$ The mass migration of Indian labour until 1957 increased the number of Indian labours in the Straits Settlements and the Federated Malay States. The number of labourers in 1891 was around 75,000, increased to 120,000 people in $1901,267,159$ in $1911,471,536$ people in 1921 , and 621,774 people in $1931 .^{21}$

The arrival of Indians to Malaya brought about a new change in their way of life. A large number of Indians were temporary plantation workers, while a small number were involved in other occupations, such as being labourers in government departments, or clerks. $^{22}$ This discussion focuses on the social lives of plantation Indians, highlighting the aspects of mistreatment, work-related stress, the caste system, basic facilities, habitation, religious service, wage, recreational activities, and so on. A discussion on these aspects is important as they bore direct relations with the subject of study, which are the binds and pressure within the plantation system.

The estate Indian community in this study refers to Indian labourers working in rubber plantations and lived according to the constraints set by the estate management. ${ }^{23} \mathrm{As}$ plantation labourers, they have to do seven to eight hours of hard work and they finish work in the evening. After this time, they have nothing else to do. ${ }^{24}$

After labourers arrive in Malaya, they were immediately sent to rubber estates. There, they were provided with basic necessities such as dwelling, clothes and food by the employers including a sundry. The British provided these facilities to prevent labourers from crossing the estate borders. In reality, Indian labourers were not allowed to go beyond the borders of their working place. The inadequate communication and transportation system, including their remote location in the interior made living there quite difficult. Outsiders were also not allowed to go into the estates. This meant the Indians effectively lived isolated from the outside world. This British action prevented social interaction, not only between estate labourers and people from other ethnic groups, but also between Indian labourer and other Indians in Malaya. Labourers were left to live as a separated community, maintaining cultural characteristics from their home with no room for change. ${ }^{25}$

The labourers had no intention of remaining in the kangani or estate lifestyle, and desired to escape the system. Any labourer that wanted to leave was forced to pay a certain amount of cash before leaving the estate. Where would these poor workers get the money when all the money received on payday was in the hand of the kangani? The employers ensured the labourers remained short on funds in order to keep them there indefinitely. This then led labourers to abandon their desire to escape the horrible estate bondage. ${ }^{26}$ In addition, most plantations employed guards / patrols to ensure workers did not cross the estate border. If a labourer wished to go to, say, the post office, a special pass would be issued to the labourer and he is accompanied by a guard to prevent him from absconding. Furthermore, the labourers were not even allowed to visit friends or relatives in other estates. This meant the Indian labourers were bound in de facto slavery. ${ }^{27}$ This situation led to labourers living stressful and difficult lives trick. 
The plantation bondage system was not only imposed on Indian labourers, and even the kanganis were bound to estate rules. In a kangani wishes to leave his estate, he must sign in one discharge note. A labourer that refused to work with low pay could follow the kangani, but after repaying compensation to the estate. The conditions in such a discharge note were strict and the Europeans were suspected of having their own play in the introduction of these notes. An example of this "discharge note" is as such, "Boarder Raman kangany and his 72 cooly were working on this Estate and they were paid off the Estate. Superintendents in this districts are specially requested not to employ them." They could not find work in other estates as a result and had to return to their old plantations and live under the same hardship. ${ }^{28}$

Overwork was the main form of mental anguish suffered by the Indian plantation labourers in Malaya. This situation is reflected in George Netto's statement, "overwork or long term of their contract or great stress is put upon the unfavourable effect upon the mind and consequently upon the physical health of cooly immigrants- a prospect that has to be faced by every new-comer and which results in many cases in despair, loss of health and death. ${ }^{29}$ This situation was also mentioned in the Annual Report published by the agent of the government of India on the conditions of Indian labourers in Malaya, released in 1927, which among other things stated, "In some of the estates, complaints were made about the difficulty of the tasks especially in silt-pit digging. Failure to come up to the prescribed task on any day entailed half-name or half-wage both for men and women irrespective of the number of hours worked by the labourers. " ${ }^{30}$ Almost all forest areas in Malaya were cleared by Indians of mainly South Indian origin. The rubber industry also grew on the backs of Indian man power. This situation clearly showed the hardships faced by Indian labourers in the estates.

The policies adopted by the British especially employers against Indian labourers have caused them to lead a very stressful life. In India, they were discriminated as lowly labourers from the lower castes, while in the estates they were greatly mistreated, to the extent that the British labelled them 'coolies', a Tamil word that meant lowly hire. The 'coolies' sat on the lowest rung of the plantation hierarchical structure, the highest being the Europeans. They have reserved dwellings far and isolated from labourers' quarters. Below the managers were Asian staffs such as clerks. This group mainly consisted of Ceylonese or Malayalees. They function as the middlemen between the managers and labourers and maintain labourer daily activity. Although the middlemen are linguistically, ethnically and culturally closer to the labourers, the former had no close relationship with the latter. This situation seemed to be planned bythe employers to prevent cordial ties between the two groups. ${ }^{31}$

The Ceylonese did not have close relations with the estate Indians. Unlike the South Indians, the Ceylonese that came to Malaya were generally British-educated and most were appointed clerks in European-owned plantations. They did not use their position to improve the base condition of the Indian labourers in the plantation sector. In fact, they sided with the labourers in their repression of the Indians. They also looked down of Indian labourers due to their low economic and social conditions. This attitude showed among Indians seeds of hatred towards the Ceylonese. ${ }^{32}$ This hatred bred from the mistreatment suffered led to the workers.

Furthermore, Indian labourers faced other problems such as discrimination among workers practised by estate employers. For example, work such as garbage collection, and drainage and toilet cleaning, was reserved for the low castes. ${ }^{33}$ This meant that within the labour class there exists a sub-class based on the nature of the work. Labourer dwellings were 
also arranged based on their caste hierarchy. The low castes were placed in houses isolated from those of higher castes. ${ }^{34}$ In some estates in Malaya, separate temples and water facilities were provided based on this caste hierarchy. ${ }^{35}$ Strict caste-ism existed in India before. In Madras for example, discrimination based on caste hierarchy was common. However, the situation in Malaya was different. Here, the lower castes were not dependent on the higher castes for their sustenance. There existed no master-servant relationship. All were equally low in the estate economic hierarchy. All were dependent on the British employers that pay their wages. In this light, the British decision to maintain caste discrimination among the labourers is very peculiar. ${ }^{36}$

The idea that the British utilised caste as a tool to keep the Indian labourers as ignorant, divided, and regressive people with no drive for self-improvement should not be easily rejected. Regardless of British intention, this mistreatment dulled the Indian labourer spirit and they lived as a divided community. British discrimination not only involved caste, but also in other aspects such as habitation, wages, and work, among other things, and this interfered with Indian life in the estates.

In view a relationship between employer and employee becoming more and more practical, it is amusing to reflect on the one-time paternal outlook without which a planter was once considered to be of little value to his Company. A symbol of this paternalism, in the form of Hindu temple, stands on the banks of the river Sungei Raia in Central Perak. This river has its source in the heart of the Cameron Highlands. It descends into Kinta Valley and joins the Kinta River on the outskirts of Batu Gajah. About three miles short of this junction the Sungei Raia touches the edge of a rubber estate and it is here that the temple is situated. To relate the story of the temple, for not only is its ornate structure of interest to passers by, but it boasts a unique feature. ${ }^{37}$

Figure 4: An old and new Mariamman Temple at Batu Gajah, Perak
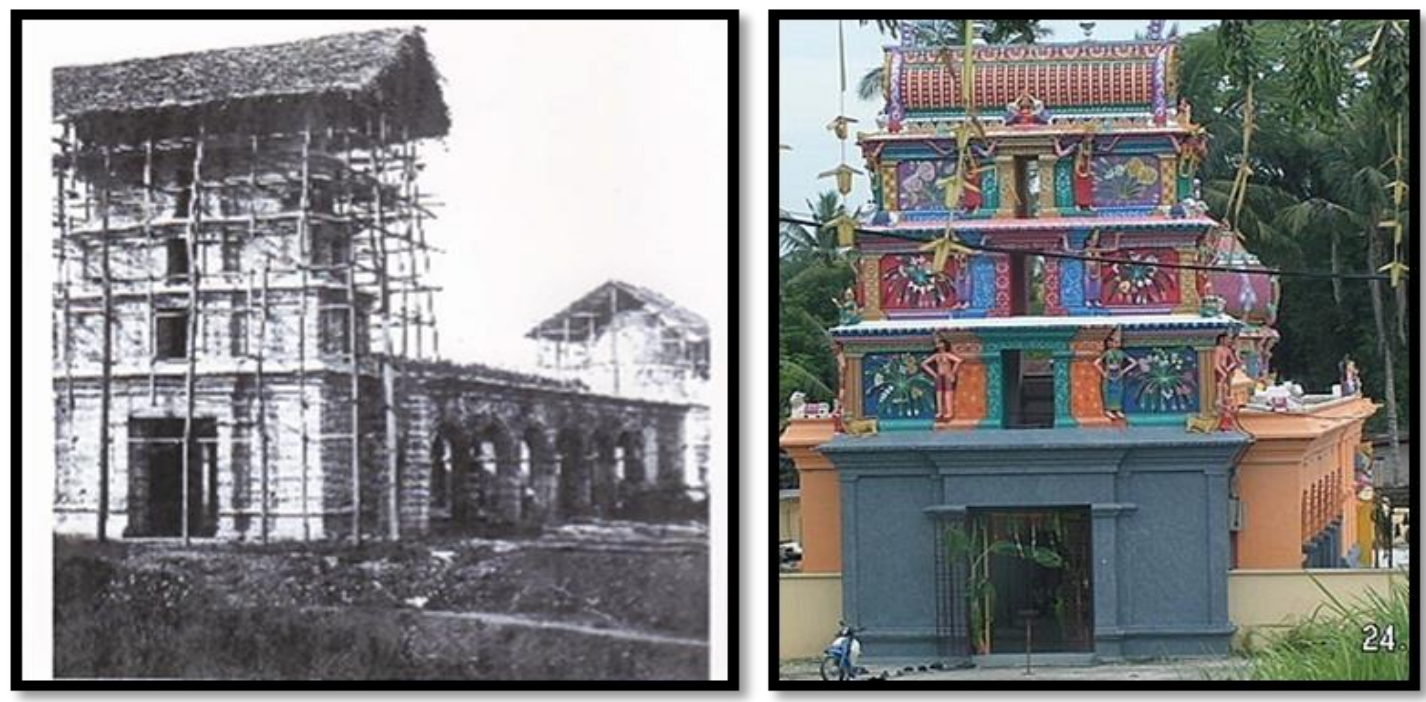

Source: National Archive of Malaysia, Kuala Lumpur 
Along the top of a wall, flanking a courtyard between the facade of the temple and its "holy of holies", stands a row of images. A popular deity is depicted with an arm around each of his wives, while nearby is the figure of an armed European in the role, it would seem of bodyguard. ${ }^{38}$

Among the South Indian labourers is an old man called Veeran who claims to have been on the estate when the temple was built and to remember the events which led to a European being appointed to this position of honour. It is many years since Veeran became too old to tap rubber. He refused to retire, however and pleaded to be appointed watchman. His sight not being what it was in 1903 when he left his native village in South India to seek his fortune in Malaya, there was little that he could watch. His wish was nevertheless granted and remains a watchman to this day. ${ }^{39}$ From the report given by Veeran found that:

One day we were told that it had ended and that the English had won. There was much rejoicing, but the war was soon followed by a great sickness. All over the world people became ill and here, in Malaya, to add to our troubles, there was a shortage of rice. The gods were angry and the time had come to placate them. We considered by what means this should be done and decided to build a temple in their honour. We therefore approached the dorai, for we hadn't the money to build it ourselves. ${ }^{40}$

Many of the workmen were Indians. In the early 1920s a flu epidemic occurred and many of his estate workers died. The Indians asked for a temple to be built in honour of the deity Mariamman who would hopefully give them protection. Then, Indian labourers around Batu Gajah ask Kelly Smith to help them to build a temple to the goddess Mariamman. Here is a report taken from Veeran:

'Dorai', we said, we know that you are a very rich man and what is more, a very good one. But it grieves us to think that you have no son and heir. Now, if you build us a temple, we will pray to the goddess Mariamma to present your mem with a son and then your cup will surely be full. ${ }^{41}$

From Veeran evidence was found that, Kellie Smith then agreed to build Mariamma temple. The temple was soon built and was $1500 \mathrm{~m}$ from the house. This situation occurs when Kellie Smith see the power of the goddess Mariamma. This can be seen in the following description:

The dorai said he would think the matter over. We wasted no time, however and made an offering of fruit and flowers to the goddess. You may imagine our joy and surprise when, a week later, we discovered the flowers had not withered. We took the flowers to the mem and both she and the dorai were much impressed. They said it was a clear sign that our prayers would be answered. The dorai was busy, at the time, in building himself a very large bungalow, but he gave orders that work should immediately cease, and he transferred all his workers to a site which we had chosen for the temple. He sent to India for experience sculptors to fashion the gods and declared that the temple would be the best of its kind in Malaya. A year or two passed, we 
heard that the mem was expecting a child. There was much excitement. The finishing touches to the temple were hastily put in hand and, within a few days of its being consecrated, the mem gave birth to a son. ${ }^{42}$

As the final word, Veeran's report prove that the close relationship between Kellie Smith with Mariamma temple can not be separated. Without Kellie Smith, we are unlikely to get a very unique temple on this day. According to Veeran:

What greater proof could there be of the dorai's worthiness of a place among the gods? We accordingly fashioned a likeness of him a clay, and he has kept watch over the temple ever since. Before resuming work on his bungalow, the dorai took a trip to England, no doubt to report these strange happenings to the king. We were sorry to see him go, but were quite sure he intended returning, for he left behind many of his possessions. He had not been away for long, however, when to our great grief we heard that he had died. Bit his spirit was captured in the image which you see and we believe that he is as much alive as the gods among whom he stands. ${ }^{43}$

Photo 5: William Kellie Smith on the Temple Roof of a Colonial-looking Man Dressed in a White Topee, Green Jacket and Khaki Coloured Pants

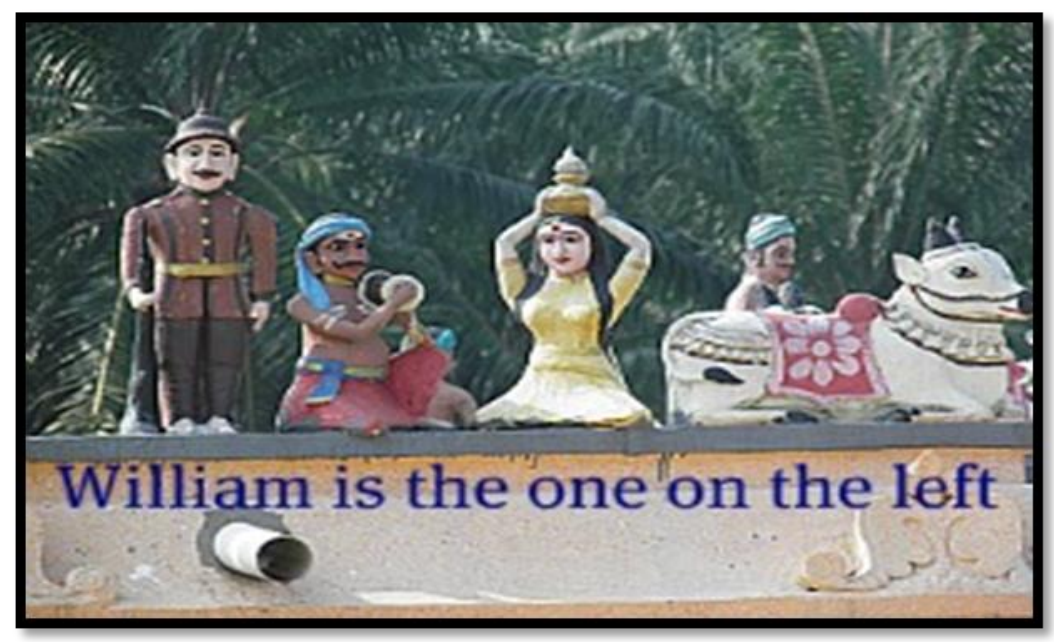

Source: National Archive of Malaysia, Kuala Lumpur.

Apart from the uniqueness of Kellie castle, there is another uniqueness that has been built by William especially three underground tunnels. One of these tunnels connect Kellie Castle with Mariamma temple. But apart from two tunnels none were ever found. The Museum of Antiquities refurbished parts of the castle, mostly in the old wing by replastering the walls and laying floor tiles. An interesting discovery was made in June 2003. During the course of widening the Gopeng - Batu Gajah road at the 6th kilometre stretch, workers unearthed a section of a tunnel. This $1.5 \mathrm{~m}$ high by one-metre wide passageway is believed to lead from the castle to the Hindu temple nearby. It is also believed that a tunnel connecting the castle to the temple was built for his family so that they could visit the temple regularly. ${ }^{44}$ 
From the above discussion it is clear that, without William Kellie Smith, the Indians would not have a unique temple and is one of the oldest temples in the state of Perak. William Kellie Smith has played a very significant role in the history of Malaya, especially in the Indian community. This is so because the castle was built by William Kellie Smith is a first palace with 'lift' and the oldest in Malaysia today. In addition, it is desirable to note that Mariamma temple built by Kellie Smith has many peculiarities in terms of construction and structure of the temple as well as an underground tunnel connecting the palace the palace of Kellie Smith. Another uniqueness of this temple is, a European get a place among the gods. It is something of a miracle and amazing things.

\section{Conclusion}

Kellie Smith was a man of great vision and enterprise and he appears to have shared that enjoyment of technological advance and development which so often types pioneering man. The love of motor cars, the self-confidence and ebullience of building a house modelled on the Secretariat in Kuala Lumpur, the plan to install a lift combine to create the image of a man who was slightly larger than life.

Now the castle has been turned into a tourist attraction. The grounds have been restored and visitors can now explore the empty wine cellar, the cool and shady rooms of the castle, and the ruins of the family's old home beside it. Today the Sri Maha Mariamman temple is still used by the local Indian community. If you look closely at the statues of the deities on the temple roof, you will see a figurine of a colonial-looking man dressed in a white topee, green jacket and khaki coloured pants. This is William Kellie Smith. It is thought the workers put it there to honour Smith for building the temple for them. Smith still stands with the deities watching over his estate. And there are still mysteries and folklore associated with Kellie's Castle and the Sahib of the Kinta Estate.

\footnotetext{
Note

* Dr. Parameswari Krishnan (param@unisel.edu.my) is a lecturer in the Faculty of Education and Social Sciences, University of Selangor, Selangor and she is working on the Malaysian History, Social History and Humanities in Colonial Malaya and Malaysia.

* Dr. J.Hinduja Jayer Raman (hindujkh_87@yahoo.com) is a graduate from University of Malaya (UM) and now she is working on the Sociology and Humanities in Malaysia.

*** Mr. Said Darkasi (saiddarkasi@unisel.edu.my) is a lecturer in the Faculty of Education and Social Sciences, University of Selangor, Selangor and he is working on the Education and Humanities in Malaysia.

${ }^{1}$ William Kellie Smith, Maps, Newspaper Cutting and Photographs, 1977-1986, in Surat Persendirian Tan Sri Datuk Haji Mubin Sheppard, 2000/0007397, p. 2.

${ }^{2}$ Ibid.

${ }^{3}$ Ibid.

${ }^{4}$ Ibid.

${ }^{5}$ Ibid, p. 3. See also, Pamela Mace, 'The Houses that Kellie Smith Built', Pelita, Vol. 2, 1982, pp.1-7.

${ }^{6}$ Pamela Mace, 'The Houses that Kellie Smith Built', Pelita, Vol. 2, 1982, pp. 1-7.

${ }^{7}$ William Kellie Smith, Correspondence and Papers, 1977-1986, in Surat Persendirian Tan Sri Datuk Haji Mubin Sheppard, 2000/0007398, p.4.

${ }^{8}$ Pamela Mace, 'The Houses that Kellie Smith Built', Pelita, Vol. 2, 1982, pp. 1-7.
} 
${ }^{9}$ William Kellie Smith, Maps, Newspaper Cutting and Photographs, 1977-1986, in Surat Persendirian Tan Sri Datuk Haji Mubin Sheppard, 2000/0007397, pp. 2-3.

${ }^{10}$ Ibid., p. 3.

${ }^{11}$ Ibid.

${ }^{12}$ Ibid., 4.

${ }^{13}$ C. C. P. Wilkins, 'Kellie's Castle', Journal of The Malayan Historical Society, No. 2, Vol. 7, July 1962, p. 27.

14 William Kellie Smith, Correspondence and Papers, 1977-1986, in Surat Persendirian Tan Sri Datuk Haji Mubin Sheppard, 2000/0007398, p.7.

${ }^{15}$ In this system, coolies gathered in India were stored in depots in Nagapatnam or in other harbours until the number of labourers sufficed. They were then sent to the ship owner and escorted by the maistry (mandor / kangani) to the destination harbour. There, they were sold under the contact system to serve at a given period. See, K. S. Sandhu, Indians In Malaya: Some Aspect of their Immigration and Settlement, 1786-1957, London: Cambridge University Press, 1969, p. 79.

${ }^{16}$ George Netto, Indians In Malaya: Historical Facts and Figures, Singapore: Author, 1961, pp. 35-42.

${ }^{17}$ Usha Mahajani, The Role of Indian Minorities in Burma and Malaya, New York: Vora\& Co, Publishers Private Ltd., 1960, p. 97.

${ }^{18}$ K.Anbalakan, Identiti India Di Malaysia (Indian Identity in Malaysia), Pulau Pinang: Universiti Science Malaysia Publisher, 2008, p. 5.

${ }^{19}$ Usha Mahajani, The Role of Indian Minorities in Burma and Malaya, pp. 96-97.

${ }^{20}$ K.Anbalakan,Identiti India Di Malaysia, p. 8.

${ }^{21}$ Ooi Jin Bee, Land, People and Economy in Malaya, London: Longmans, 1967, p. 117.

${ }^{22}$ C.O. 273/405, Letter from Rayappan, Seremban, 25 March 1913, p. 7.

${ }^{23}$ Ibid., p. 6.

${ }^{24}$ C.O. 438/5, Federated Malay States, Annual Report On The Social and Economic Progress Of The People Of Perak For The Year 1935, Kuala Lumpur: F.M.S. Government Press, 1936, p. 96.

${ }^{25}$ K. Anbalakan, Identiti India Di Malaysia, pp. 6-7.

${ }^{26}$ C.O. 273/405, Letter from Rayappan, Seremban, 25 March 1913, p. 5.

${ }^{27}$ Ibid.,p. 6.

${ }^{28}$ C.O. 273/405, Letter of K. Nagamuthu, Kapar, 30 April 1913,pp. 1-2.

${ }^{29}$ George Netto, Indians in Malaya: Historical Facts and Figures, p. 37.

${ }^{30}$ Annual Report of The Agent of The Government of India In British Malaya For The Year 1927, Calcutta: Government of India, Central Publication Branch, 1928, p. 9.

${ }^{31} \mathrm{~K}$. Anbalakan, Identiti India di Malaysia, pp. 8-10.

${ }^{32}$ Ibid.,p. 25.

${ }^{33}$ Wiebe \& Mariappan, Indian Malaysians: The View From The Plantations, New Delhi: Manohar Publications, 1978, p. 72.

${ }^{34}$ According to Wiebe and Mariappan, this practice existed in the studied estates until the 1950s. See, Wieve \& Mariappan, Indian Malaysians: The View From The Plantations, p. 72.

${ }^{35}$ S. Arasaratnam, Indians in Malaysia and Singapore, Kuala Lumpur: Oxford University Press, 1970, p. 65.

${ }^{36}$ K. Anbalakan,Identiti India di Malaysia, p. 11.

${ }^{37}$ C. C. P. Wilkins, 'A Guardian of the Gods', pp. 45-46, in William Kellie Smith, Correspondence and Papers, 1977-1986, Surat Persendirian Tan Sri Datuk Haji Mubin Sheppard, 2000/0007398.

38 Ibid.

${ }^{39}$ Ibid.

${ }^{40}$ Ibid. See also, C. C. P. Wilkins, 'Kellie's Castle', Journal of The Malayan Historical Society, No. 2, Vol. 7 , July 1962, pp. 27-28.

${ }^{41}$ C. C. P. Wilkins, 'Kellie's Castle', Journal of The Malayan Historical Society, No. 2, Vol. 7, July 1962, p. 28.

42 Ibid. See also, C. C. P. Wilkins, 'A Guardian of the Gods', pp. 45-46, in William Kelly Smith, Correspondence and Papers, 1977-1986, Surat Persendirian Tan Sri Datuk Haji Mubin Sheppard, 2000/0007398

${ }^{43}$ Ibid.

44 'The Secret Tunnels of Kellie's Castle', The Brunai Times, $1^{\text {st }}$ November 2008. 


\section{Reference}

Anbalakan, K., Identiti India Di Malaysia (Indian Identity in Malaysia), Pulau Pinang: Universiti Science Malaysia Publisher, 2008.

Annual Report of The Agent of The Government of India In British Malaya For The Year 1927, Calcutta: Government of India, Central Publication Branch, 1928.

Arasaratnam, s., Indians in Malaysia and Singapore, Kuala Lumpur: Oxford University Press, 1970.

C.O. 438/5, Federated Malay States, Annual Report On The Social and Economic Progress Of The People Of Perak For The Year 1935, Kuala Lumpur: F.M.S. Government Press, 1936.

C.O. 273/405, Letter from Rayappan, Seremban, 25 March 1913.

C.O. 273/405, Letter of K. Nagamuthu, Kapar, 30 April 1913.

George Netto, Indians In Malaya: Historical Facts and Figures, Singapore: Author, 1961.

Ooi Jin Bee, Land, People and Economy in Malaya, London: Longmans, 1967.

Pamela Mace, 'The Houses that Kellie Smith Built', Pelita, Vol. 2, 1982.

Sandhu, K.S., Indians In Malaya: Some Aspect of their Immigration and Settlement, 17861957, London: Cambridge University Press, 1969.

'The Secret Tunnels of Kellie's Castle', The Brunai Times, $1^{\text {st }}$ November 2008.

Usha Mahajani, The Role of Indian Minorities in Burma and Malaya, New York: Vora\& Co, Publishers Private Ltd., 1960.

Wiebe \& Mariappan, Indian Malaysians: The View From The Plantations, New Delhi: Manohar Publications, 1978.

William Kellie Smith, Maps, Newspaper Cutting and Photographs, 1977-1986, in Surat Persendirian Tan Sri Datuk Haji Mubin Sheppard, 2000/0007397.

William Kellie Smith, Correspondence and Papers, 1977-1986, in Surat Persendirian Tan Sri Datuk Haji Mubin Sheppard, 2000/0007398.

Wilkins, C.C.P., 'Kellie's Castle', Journal of The Malayan Historical Society, No. 2, Vol. 7 , July 1962.

Wilkins, C.C.P., 'A Guardian of the Gods', pp. 45-46, in William Kelly Smith, Correspondence and Papers, 1977-1986, Surat Persendirian Tan Sri Datuk Haji Mubin Sheppard, 2000/0007398. 